\title{
A Method to Determine Lethal and Sublethal Concentrations of Recombinant Bioinsecticides Derived from Bacillus thuringiensis Against Larvae of Spodoptera litura \\ El- Adl, A. M. ${ }^{1}$; K. A. Zaied ${ }^{1}$; Kawther S. Kash ${ }^{1}$; A. I. El Sayed ${ }^{2}$ and Mervat I. kamal ${ }^{1}$. \\ ${ }^{1}$ Department of Genetics, Faculty of Agriculture, Mansoura University, Egypt. \\ ${ }^{2}$ Water, Soil and Enviromental Researsh Institute, Agric. Researsh Center, Giza, Egypt.
}

\begin{abstract}
The increased awareness of environmental pollution have led to the growing interests of the application of biological agents to control insects such as lepidopteran family. Thus, this study aimed to produce genetically improved bioinsecticide agents to be used to control Spodoptera litura which would be useful in reducing environmental pollution ,preventing resistance to bioinsecticides and for safe food production .Four Bacillus thuringensis strains were used as recipients ' while ' Seratia marcescens was used as a doner strain in the conjugation to induce new recombinants in Bacillus thuringiensis over expressed chitinase.Four matings were conducted in this study between Serratia marcescence and the four Bacillus thuringiensis strains which having opposite genetic markers.Two efficient transconjugants based on chitin hydrolysis on agar medium were selected from each conjugation to be evaluated for toxicites against the larvae of cotton leafworm in relation to their parents .The efficient $\mathrm{LC}_{50}$ was appeared by $\operatorname{Tr}_{4}\left(1.93 \times 10^{5} \mathrm{ppm}\right)$ followed by $\operatorname{Tr}_{6}$ and $\operatorname{Tr}_{7}\left(2 \times 10^{5} \mathrm{ppm}\right)$. However, more than $995 \%$ toxicity index was recorded by $\operatorname{Tr}_{4}, \operatorname{Tr}_{6}$ and $\operatorname{Tr}_{7}$. Higher toxicity index observed by these transconjugants may be the related to the overexpression of chitinase genes.Therefore, the lethal concentration values obtained was necessary to kill $50 \%$ of larval population from Spodoptera litura in a certain period. The virulence of Bt strains showed that a lower concentration from $\operatorname{Tr}_{4}$ was required to kill $100 \%$ of larval population.It must be pointed out that higher toxicity index obtained by transconjugants reflected the interaction between crystal genes from $B t$ and chitinase genes from Seratia marcescens which enhanced the possibility of larval mortality as a genetic helpful tool in integrated pest management in cotton fields.
\end{abstract}

Keywords : Conjugants, Spodoptera litura, Bacillus thuringiensis , $\mathrm{LC}_{50}$, Serratia marcescens .

\section{INTRODUCTION}

Cotton considered to be one of the most important crops and a major source of the national economy in Egypt. The Egyptian cotton leaf worm , Spodoptera littoralis is the most harmful cotton pests (Korrat et al. 2012). It is also a considerable cause of economic loss of many vegetables and field crops (Isman et al. 2007). Different kinds of insecticides are used to control this pest which cause a great damage and pollutions to the environment. Thus, the use of microbial pesticides for protecting crops from insect pests has assumed greater importance in recent years replace the harmful applications of the chemical pesticides (Chari et al. 1990). Thus, control of crop pests by the use of biological agents holds great promise as an alternative to the use of chemicals. Crude enzyme from different types of microorganisms have been used to control crop pest populations (Kramer et al. 1997). Bacillus thuringiensis $(B t)$ is a ubiquitous gram positive, spore forming bacterium that forms a parasporal crystal during the stationary phase of its growth cycle. $B t$ was initially characterized as an insect pathogen and its insecticidal activity was attributed largely or completely to the parasporal crystals and also to the vegetative insecticidal proteins that producing by $B t$ during its vegetative growth stage (Fang et al. 2009). $B t$ is now the most widely used biological produced pest control agent and the foliar sprays from it plays a role in the integrated pest management strategies (Crickmore, 2006). Commercial preparations from Bt are based essentially on a mixture of spores and crystals (Moore and Navon, 1973).

Genetic transfers such as conjugation are important phenomena affecting evolution and have been used in genetic engineering laboratories to transfer genes of interest to allow their expression in target organisms (Somkiat et al. 2007). Bacterial conjugation is a horizontal gene transfer process from a donor cell bearing one or more conjugative plasmids to the recipient cell plasmid - free .Conjugative plasmids in most bacteria can even be transferred to distantly related or even unrelated microorganisms (Biedendieck et al. 2007). Selectable genetic markers are an important tool in the construction of bacterial transconjugants .Ideally, the genetic markers allow for efficient selection without affecting any cellular functions (Hentges et al. 2005). Resistance to antibiotic can be conferred by chromosomal or mobile genetic element (plasmids) (Jain et al. 2009). In nature plasmids increase bacterial genetic diversity and promote bacterial adaptation by horizontal gene spread (Gogerten et al. 2002).

Chitin is a long unbranched polysaccharide of an amino sugar (Chuan, 2006). It is abundant in nature as a structural in cuticle and integument of animals, especially in insects (Arakane and Muthukrishnan, 2010). Insect growth and development are strongly dependent on the construction and remodeling of chitinous structures. Chitinase induced damage to the peritrophic membrane in the insect gut causes a significant reduction in nutrient utilization and consequently in insect growth ( Merzendorfer and Zimoch, 2003 ). Chitinase present in insect diet can decrease insect growth (Fitches et al. 2004). Chitinolytic bacteria such as Serratia marcescense have many potential applications as biocontrol agents (Wang et al. 2006). Over - expression of chitinase in entomopathogenic organism can increase insect mortality (Fan et al. 2007). This resarch aimed to calculate the lethal and the sublethal concentrations of recombinant biological control agents produced from the conjugation between Serratia marcescence and Bacillus thuringiensis and to select the effective doses 
which would be used for biological control against cotton leaf worm.

\section{MATERIALS AND METHODS}

Bacterial strains : Bacterial strains used in this study, as well as, their references, or sources are listed in Table 1.

Table 1. Bacterial strains used in this study.

\begin{tabular}{|c|c|c|}
\hline$\overline{\text { Strains }}$ & Source or reference & Designation \\
\hline Serratia marcescens & $\begin{array}{l}\text { Microbiology Dept., Soil, } \\
\text { water and Environmental } \\
\text { Research Institute, } \\
\text { Agricultural Research }\end{array}$ & $S m$ \\
\hline Bacillus thuringiensis & $\begin{array}{l}\text { Center (ARC). } \\
\text { Microbiology Dept., Soil, } \\
\text { water and Environmental } \\
\text { Research Institute, } \\
\text { Agricultural Research } \\
\text { Center (ARC). }\end{array}$ & $B t_{1}$ \\
\hline Bacillus thuringiensis & $\begin{array}{c}\text { Bacillus Genetics Stock } \\
\text { Center, Biochemistry Dept., } \\
\text { Ohio, University, } \\
\text { Columbus, USA }\end{array}$ & $B t_{2}$ \\
\hline Bacillus thuringiensis & $\begin{array}{c}\text { Bacillus Genetics Stock } \\
\text { Center, Biochemistry Dept., } \\
\text { Ohio state, University, } \\
\text { Columbus, USA }\end{array}$ & $B t_{3}$ \\
\hline $\begin{array}{l}\text { Bacillus thuringiensis } \\
\text { NRRL-HD110 }\end{array}$ & $\begin{array}{l}\text { National Center for } \\
\text { Agriculture Utilization } \\
\text { Research, USA }\end{array}$ & $B t_{4}$ \\
\hline
\end{tabular}

Media : Bacillus strains were maintained on TGY medium as a complete medium according to Harris et al. (2004). This medium was used for genetic marking bacterial strains against antibiotics.

Peptone yeast extract medium (PWYE): This medium was used for separation of crystals and endospores according to Karamanlidou et al. (1991).

Peptone glycerol medium (PGM) : This medium was used to enhance pigmentation. according to Harris et al. (1992).

Luria-Bertani medium (LB) : This medium was used in mating experiments according to Ausubel (1987).

Mineral Medium (MM) : This medium was used for screening chitinase producing bacteria which was performed on colloidal chitin agar medium and incubated at $37^{\circ} \mathrm{C}$ according to Someya et al. (2011).

Minimal Sporulation Medium ( MSM ) : The conditions for growth and sporulation were as previously described (Ellar and posgate, 1974), with the exception of a modified sporulation medium used by Gordon et al. (1981).

Antibiotics used : However, antibiotic resistance markers are alternative to auxotrophic markers. .Thus, 14 antibiotics were used in this study with different concentrations $(\mu \mathrm{g} / \mathrm{ml})$ for genetically marking bacterial strains as shown in Table 2.

Target insect : A wild type strain of $S$. littoralis used in this study was collected from the Experimental Farm of Faculty of Agriculture inside the Camps of Mansoura University in June 2015. This strain was collected as a colony of eggs on cotton and Ricinus communis leaves which were not previously exposed to any insecticides. Egg masses were kept in glass jars $(500 \mathrm{ml})$ covered with cotton cloth. The jars were daily supplemented with fresh castor bean leaves as a source of food till hatching. Newly hatched larvae at six days old were offered castor bean leaves treated with bioinsecticides via a dipping technique, although leaves dipped in water served as control.

Table2. Different antibiotics and their concentrations used for genetic marking bacterial strains.

\begin{tabular}{lcc}
\hline Antibiotics & Abbreviations & $\begin{array}{c}\text { Concentration } \\
(\boldsymbol{\mu g} / \mathbf{m l})\end{array}$ \\
\hline Chloramphenicol & $C m$ & 35 \\
Ampicillin & $A p$ & 50 \\
Tetracycline & $T c$ & 20 \\
Penicillin & $P c$ & 150 \\
Neomycin sulphate & $N m$ & 800 \\
Erythromycin-ethlsuccinate & $E r y t h$ & 20 \\
Rifampicin & $R i f$ & 150 \\
Vancomycin & $V c$ & 150 \\
Hibiotic & $H b$ & 400 \\
Amoxycillin & $A m$ & 400 \\
Ceftazidime & $C e$ & 400 \\
Cefotaxime & $C f$ & 400 \\
Cefoperazone & $C p$ & 150 \\
Genamycin & $G m$ & 20 \\
\hline
\end{tabular}

Insects were reared on castor bean leaves in laboratory under constant conditions of $27 \pm 2{ }^{\circ} \mathrm{C}$, photoperiod of $14 \mathrm{hrs}$ light and $10 \mathrm{hrs}$ dark .Larvae of S. littorails were put in glass jar $(250 \mathrm{ml})$ and feeding on treated castor bean leaves added daily .

Genetic marking : Susceptibility to antibiotics was measured by plate diffusion method according to Collins and lyne (1985) using cultures grown to logarithmic growth phase in TGY broth. The plates were incubated for $48 \mathrm{hrs}$ at $28^{\circ} \mathrm{C}$ and the diameter of resulting clear zones of inhibition was measured according to Toda et al. (1989).

Plasmid transfer via conjugation process : Mix $5 \mathrm{ml}$ of the donor strain with $5 \mathrm{ml}$ of the recipient strain in a test tube and incubated at $28^{\circ} \mathrm{C}$ for five, ten and fifteen days. At the end of mating time, the mating cells were plated on LB agar medium supplemented with selective antibiotics and incubated at $28^{\circ} \mathrm{C}$ for $48 \mathrm{~h}$. Single colonies appeared on selective medium were picked up and grown on LB slant agar medium according to Grinsted and Bennett (1990).

Preparing of colloidal chitin : Colloidal chitin was prepared from chitin flakes by the method of Mahadevan and Crawford (1997). The chitin flakes were ground to powder, added slowly to $10 \mathrm{~N} \mathrm{HCl}$ and kept overnight at $4^{\circ} \mathrm{C}$ after vigorous stirring. The suspension was added to cold $50 \%$ ethanol with rapid stirring and kept overnight at $25^{\circ} \mathrm{C}$. The precipitate was collected and washed with sterile distilled water until the colloidal chitin became neutral $(\mathrm{pH} \mathrm{7.0)}$ ) and stored at $4^{\circ} \mathrm{C}$ until further use.

Screening chitinase producing bacteria : For enrichment chitinase-producing bacteria, a mineral medium (MM) containing colloidal chitin as a sole carbon and energy source was used. Chitinolytic activity was measured by observing the size of the halo zones formed around the colonies after seven days of incubation at $30^{\circ} \mathrm{C}$ according to Someya et al. (2011). 
Separation of crystals and endospores : Bacteria were grown in petri dishes. The spores were collected from nutrient agar plates washed three times in ice-cold distilled water. Pellets (spores and crystals) were resuspended in small volumes of distilled water. The bacterial suspension cultures were prepared as follows. Loopfuls from bacterial colonies with spores and crystals were transferred to $1 \mathrm{ml}$ of distilled water. Heatshocked $\left(70^{\circ} \mathrm{C}\right.$ for $\left.30 \mathrm{~min}\right)$ suspensions were transferred to $250 \mathrm{ml}$ of PWYE medium and incubated at $30^{\circ} \mathrm{C}$ for 8 to $15 \mathrm{~h}$ with shaking at $180 \mathrm{rpm}$. Two milliliters of the PWYE culture was used to inoculate 1 liter of minimal sporulation medium ( MSM ) and was incubated at $30^{\circ} \mathrm{C}$ for 3 to 4 days with shaking at $180 \mathrm{rpm}$; at least $90 \%$ of bacterial cells were lysed releasing spores and crystals after this incubation. Spores and crystals were collected by centrifugation $(10,000 \mathrm{x} \mathrm{g}$ for $10 \mathrm{~min})$. Pellets were washed three times with ice-cold distilled water, and final pellets were resuspended in $20 \mathrm{ml}$ of water and stored in refrigerator freezer (Karamanlidou et al. 1991).

\section{Bioassay techniques}

Toxicity tests in laboratory experiment : This study was conduced in Microbial Genetics Laboratory , Faculty of Agriculture, Mansoura University through the academic years of 2013 / 2014 , 2014 / 2015 and 2015 / 2016 . To assess the activity of bioinsecticides a series of five concentrations were prepared in distilled water which were as follows; $0.0,2 \times 10^{5}, 4 \times 10^{5}, 6 \times$ $10^{5}$ and $8 \times 10^{5} \mathrm{ppm}$. The dipping technique was adopted as described by Tabashnik et al. (1991), where fresh clean castor bean leaves (Ricinus communis) were immersed in each of the tested concentration for $30 \mathrm{sec}$. Nine bioinsecticides were used including control with three replicates were used for each concentration. Castor oil leaves were first washed with distilled water then dipped in bioinsecicide suspension of each concentration for $30 \mathrm{sec}$ and allowed to air dry for one hour at room temperature before being offered to $S$. littoralis larvae.These leaves were used to feeding cotton leaf worm.

Bioassay experiment was conducted in plastic clean jars $(250 \mathrm{ml})$, each jar contained 15 larvae. A similar number of larvae were considered as a control in which larvae were offered castor been leaves immersed in distilled water. The bioassay jar was covered by a cotton tissue fixed with rubber band to prevent larvae from escaping. After dryness the bioinsecticide film on the leaves, the larvae were transferred into clean jars individually .The effects of bioinsecticides were evaluated against six - days - old larvae of cotton leaf worm, Spodoptera littoralis (mean body weight $=53$ $\mathrm{mg}$ ) at $25{ }^{\circ} \mathrm{C}$ under laboratory conditions. Larvae were fed for $24 \mathrm{hr}$ on three grams of treated leaves added daily to a new breeding bottle. After $24 \mathrm{hr}$, the survived larvae were transferred to clean jars and supplemented with treated leaves expect the control supplemented untreated leaves until pupation. The leaves were removed after $24 \mathrm{hr}$ and replaced by another treated ones after the jars were cleaned and dryed .Larval mortality was recorded daily up to pupation developed .Mortality percentage was corrected by abbott formula (Abbott, 1925) as follows:

Abbott's formula: -

Mortality \% $=\frac{\text { Control survival }- \text { Treatment survival }}{\text { Control survival }} \times 100$

The survived larvae were pooled and counted daily, then transferred to clean jars supplemented with treated leaves until pupation (Karamanlidou et al. 1991).

Determination of Lethal Concentration (LC) values : The $\mathrm{LC}_{30}, \mathrm{LC}_{50}, \mathrm{LC}_{70}$ and $\mathrm{LC}_{90}$ values were determined from leaf dipping technique at which five different concentrations of the tested bioinsecticides were used .The lethal concentration values were statistically estimated by milligrams per liter from regression lines according to Finney (1971).

Statistical analysis : Lethal concentration fifty $\left(\mathrm{LC}_{50}\right)$ of larval population was calculated from regression curves which were diagrammed according to Snedecor and Cochran (1955).

\section{RESULTS AND DISSCUTION}

Antibiotic resistance test : The results of 14 antibiotics tested by disc diffusion method on nutrient agar plates against five bacterial strains are shown in Table 3 and Figure 1 .The resistance pattern of these strains showed multiple resistance and multiple sensitive to the antibiotics used. The result of drug resistance pattern on nutrient agar showed that Seratia marcescens was resistant to pencillin, erythromycin, ceftazimide, whereas sensitive to other antibiotics. All bacterial strains tested were resistant to penicillin and ceftazimide , whereas sensitive to cefoperazone, rifampicin and vancomycin .The resistance pattern of bacterial strains tested in this study was ranged between resistant to three antibiotics to eight. These results agreed with Luna et al. (2007), who found that B.thuringiensis isolates were resistant to amoxicillin, ampicillin, ceftriaxone, pencillin and oxacillin, while susceptible to the remaining antimicrobials used .A large variety of specific biochemical functions such as resistance to antimicrobial drugs, production of bacteriocins and production of toxins ,have been attributed to some plasmids Bernhard et al. (1978). These antibiotics all have a similar mechanism of action ,stopping bacteria from multiplying by preventing it from forming the walls that surround them (Bautista and Teves, 2013 ). The number of plasmids in $B t$ are variable from one to more than six (Carlson et al.1994).The Bt strains have different patterns of plasmids and show different toxicities against insects ( Ren et al. 1995 ).

Conjugation and hydrolysis of colloidal chitin : Conjugation between Seratia marcescens as a donar strain and different strains of Bacillus thuringiensis as a recipients was done depending on the opposite genetic markers between both strains in each conjugation. Transconjugants appeared on selective medium 
containing the opposite markers of antibiotics were picked up (Figure 2).

Ten transconjugants were taken to be used for select the efficient ones showing clear hydrolysis zone on colloidal chitin .On the basis of colloidal chitin degradation colonies were selected depending on the zone of clearance on colloidal chitin agar (CAA) plates (Figures 4 and 5 ). On the bases of maximum chitinase production, two potential isolates from esch conjugation were selected for further studies against Spodoptera litura. Therefore, conjugation might provide means of transferring DNA between strains from both genus.Today, conjugation techniques have been used in virtually all cultured Gram-negative bacteria and have been reported in several Gram-positive bacteria (Schroder and Lanka, 2005). The results obtained herein agrees with Domingues and O'Sullivan (2013), who found that conjugation efficiencies between E.coli and Bifidobacterium observed initially ranged from $10^{-4}$ to $10^{-6}$ transconjugants per recipient, which are similar to reports in other Actinobacteria. The result indicated that Serratia marcescens which used as a donar strain in this study have the ability to produce a huge amount of chitinase in short time because of complete hydrolysis of colloidal chitin agar (Figure 3). Thus, this strain was used in this study as a donar strain to transfer chitinase gens to Bacillus thuringiensis strains for increasing the control of insect pests via chitinase producing transconjugants because biocontrol efficiency have been correlated with chitinase production (Wu et al.2010). However, microbes producing chitinases have received much attention regarding their potential development as biopesticides ( Aggrawal et al. 2015) .In addition, found that the semi- synthetic diet containing sublethal doses of S.marcescens caused a dose - dependent inhibition of growth of first instar larvae .Among bacteria , $S$. marcescens have been reported to be a good producer of chitinases ( Aggrawal et al. 2015). These bacteria enzymatically cleave the chitin present in the peritrophic membrane of the insect gut causing

perforations, leading to disease and subsequent death of the infected larva (Chandrasekaran et al. 2012). Previous studies revealed that chitinase could enhance the insecticidal activity of Bacillus thuringiensis and it has been used in combination with $B$. thuringiensis widely. However, $\mathrm{Hu}$ et al. (2004) found that the expression of $B t$ chitinase in rather low and needs induction by chitin, which limits its field applications .Thus, this study taken sense to costitutively express the $B t$ chitinase at a sufficiently high level via conjugating $B t$ strains with $S$. marcescens to offer advantages in biological control of pests using recombinant isolates of $B t$.Biochemical and histochemical studies demonstrated that the insect peritrophic membrane consists of a chitin fibril network embedded in a protein - carbohydrate matrix.Pathogens have to cross the chitin - rich barrier to exert their virulence (Nation 2001).

Table 3 . Antibacterial activity of antibiotics on nutrient agar plates against Bacillus thuringiensis and Seratia marcescens.

\begin{tabular}{lccccc}
\hline Antibiotics & SM & $\mathbf{B t}_{\mathbf{1}}$ & $\mathbf{B t}_{\mathbf{2}}$ & $\mathbf{B t}_{\mathbf{3}}$ & $\mathbf{B t}_{\mathbf{4}}$ \\
\hline$C m$ & - & - & - & + & - \\
$A p$ & - & + & + & + & + \\
$T c$ & - & - & - & - & + \\
$P c$ & + & + & + & + & + \\
$N m$ & - & - & + & - & - \\
Eryth & + & - & - & - & - \\
Rif & - & - & - & - & - \\
$V c$ & - & - & - & - & - \\
$H b$ & - & + & + & + & + \\
$A m$ & - & + & + & + & + \\
$C e$ & + & + & + & + & + \\
$C f$ & - & + & + & + & + \\
$C p$ & - & - & - & - & - \\
$G m$ & - & - & + & - & - \\
\hline Abbreviation & & - & & &
\end{tabular}

Abbreviations used :

$+=$ Resistant

$\mathrm{Cm}=$ Chloramphenicol

$T c=$ Tetracycline

$N m=$ Neomycin sulphate

Eryth $=$ Erythromycin-ethlsuccinate

$\mathrm{H} b=$ Hibiotic

$C e=$ Ceftazidime

$\boldsymbol{G} \boldsymbol{m}=$ Genamycin
- =Sensitive

$A p=$ Ampicillin

$P c=$ Penicillin

Rif $=$ Rifampicin

$V c=$ Vancomycin

Am $=$ Amoxycillin

$C f=$ Cefoperazone

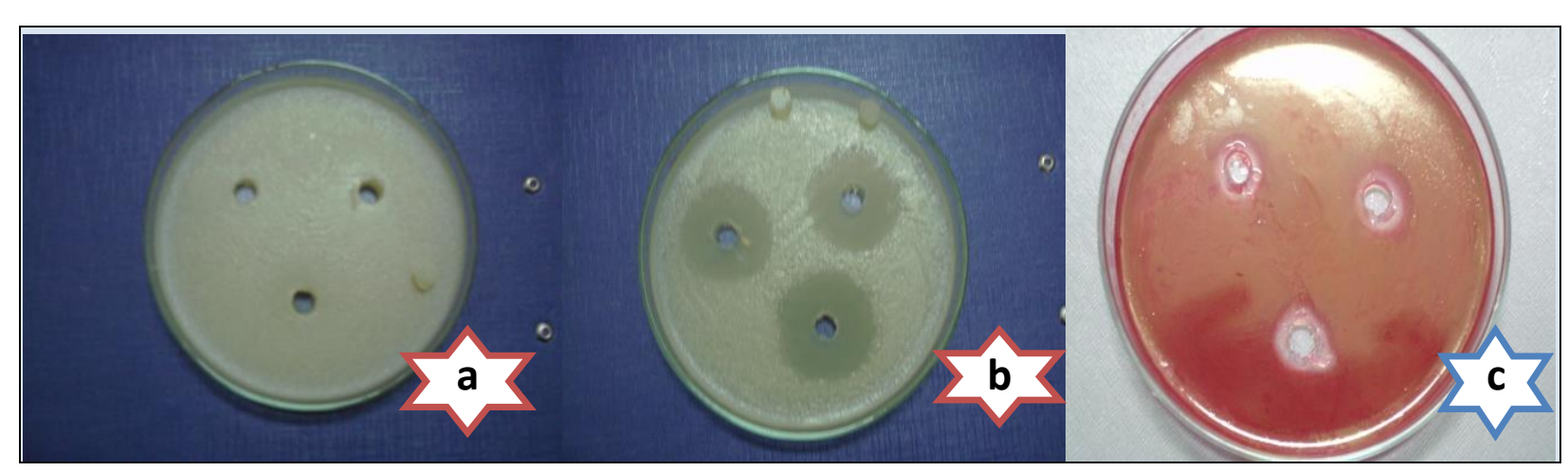

Figure 1. Bacterial colony of $\mathrm{Bt}_{3}(\mathrm{~b})$, Seratia mercescens (c) in relation to uninoculated control (a) showing clear hydrolysis zone on antibiotic agar medium in plates number $b$ and $c$. 

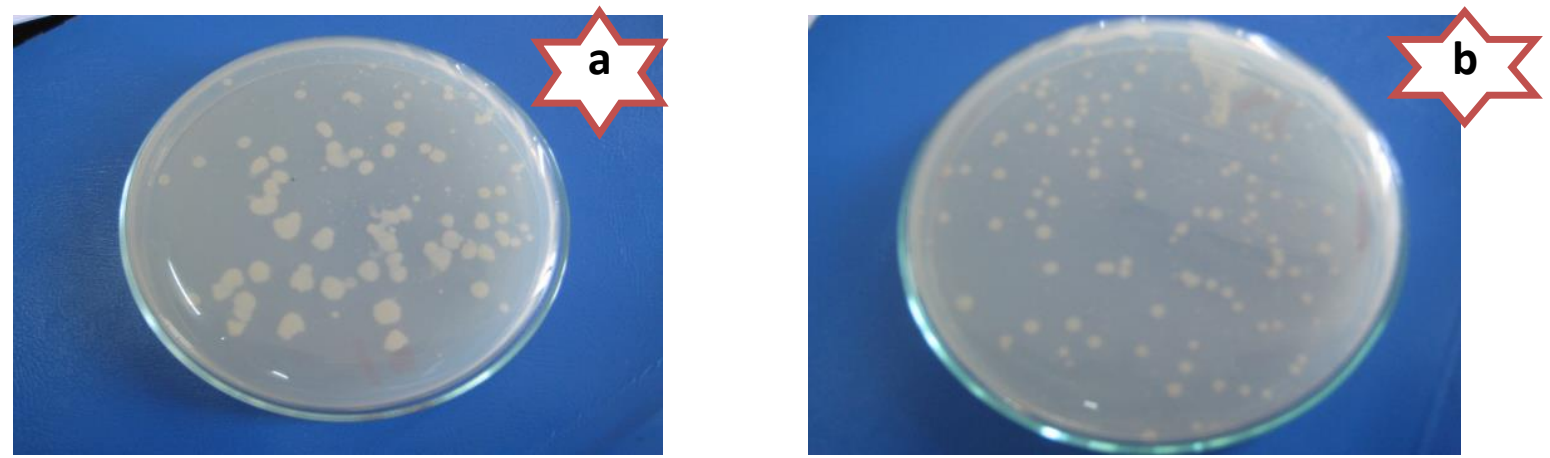

Figure 2. Bacterial colonies of recombinants resulted from conjugation between Seratia marcescens $\mathbf{x} \mathrm{Bt}_{4}$ (a) and Seratia marcescens $\mathrm{x} \mathrm{Bt}_{3}(\mathrm{~b})$.

Similar studies on the effect of different $B$. thuringiensis strains on Spodoptera littoralis have whether insects were fed crystals, solubilized crystals or in vitro activated crystals (Aronson et al. 1991). shown great variability in toxicities, depending on

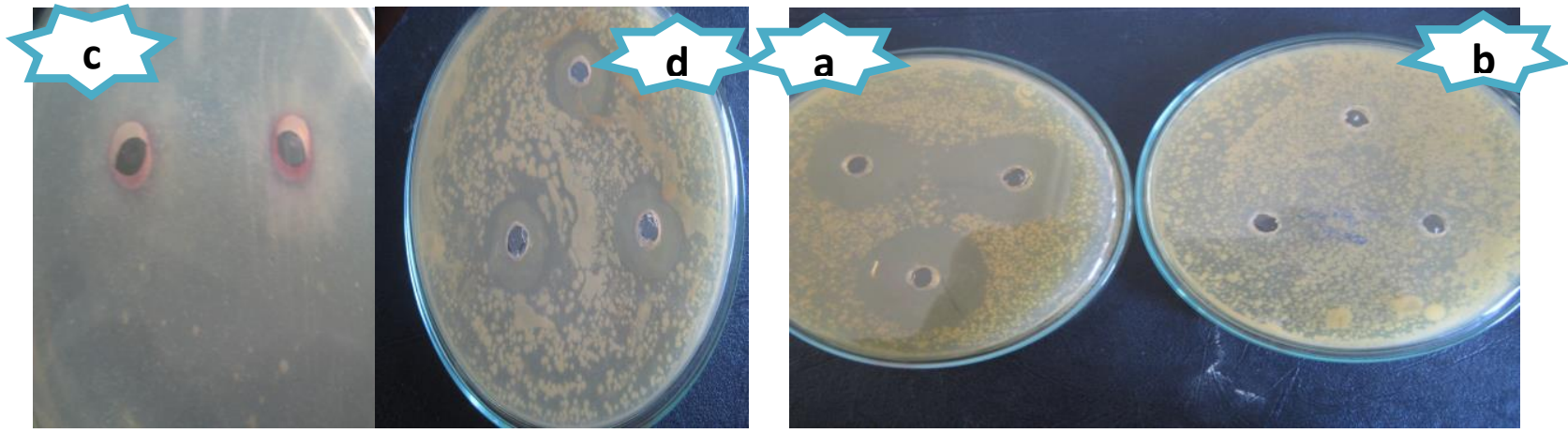

Figure 3. Colonies of $\mathrm{Bt}_{2}$ (a), Seratia marcescens (c) and $\operatorname{Tr}_{3}$ in relation to uninoculated control plate containing chitin (b) showing clear hydrolysis zone on colloidal chitin agar medium.

Lethal concentration of $\boldsymbol{B t}$ bioinsecticide: Preliminary assays in Table 4 and in Figures from 4 to 16 indicated that the efficient estimated $\mathrm{LC}_{50}$ value of $B t$ against Spodoptera littoralis larvae was appeared by $\operatorname{Tr}_{4}(1.93$ x $10^{5} \mathrm{ppm}$ ) followed by $\operatorname{Tr}_{6}$ and $\operatorname{Tr}_{7}\left(2 \times 10^{5} \mathrm{ppm}\right)$. More than $95 \%$ toxicity index was recorded by $\operatorname{Tr}_{4}, \operatorname{Tr}_{6}$ and $\operatorname{Tr}_{7}$. The LC values of $B t$ are dependent on type of recombinant crystal protein and geographical variation of the parental $B t$ strains.

These results agreed with Nguyen et al. ( 2005 ), who found that larvae of Diadegma insulare did not have enough time to complete their development in the $B t$ - infected hosts. Chilcutt and Tabashinik ( 1997a ) found that $C$. plutellae larvae were killed in hosts infected by $B t$.

The results obtained herein are in harmony with Ebrahimi et al. ( 2012 ), who found that $\mathrm{LC}_{50}$ of $B t$ against diamondback moth ( DBM ) larvae was 210 ppm, as well as , more than $80 \%$ mortality was recorded at $450 \mathrm{ppm}$ of $B t$ concentration. Higher toxicity index observed by $\operatorname{Tr}_{4}, \mathrm{Tr}_{6}$ and $\mathrm{Tr}_{7}$ may also be due to the gene expression of all three types of chitinases, viz exochitinase, endochitinase and chitobiosidase transferred from Serratia marcescens to $B t$ via conjugation. This agreed with Aggarwal et al. (2015), who found that serratia marcescens produced all three types of chitinases and caused mortality in all developmental staged of S.litura larvae with $\mathrm{LC}_{50}$ ranging from $7.02 \times 10^{3}$ to $7.29 \times 10^{7} \mathrm{cfu} \mathrm{ml}^{-1}$, as well as , $\mathrm{LT}_{50}$ for the different larval instars ranged from 3.1 days to 5.5 days . In addition, chitinase production is an important virulence factor contributing significantly to their potency as entomopathogenes Aggarwal et al. (2015).The genus Serratia contains several entomopathogenic species from which S.marcenscens has mostly been studied (Tan et al. 2006) . In bacteria, S. marcescens has been demonstrated as a good producer of chitinases. Wang et al. (2013) reported that pathogenicity of $S$. marcescens towards insects was attributed mainly to their production of chitinases and other hydrolytic enzymes.

The results obtained in this study appeared that transcojugant $\operatorname{Tr}_{4}$ is higher pathogenic causing $100 \%$ toxicity index than other bioinsecticides used in this study. The same trend was obtained by Hernadez ( 1988 ) on subspecies Bt aizawai , B. thuringiensis and Bt Kurstaki, who observing mortality of $80 \%, 100 \%$ and $70 \%$ respectively, using $3 \times 10^{7}$ cells $/ \mathrm{ml}$. The virulence assays showed that transconjugant $\operatorname{Tr}_{4}$ was the most active recombinant isolate with an $\mathrm{LC}_{50}$ of $1.93 \times 10^{5} \mathrm{ppm}$ followed by $\operatorname{Tr}_{6}, \mathrm{Tr}_{7} \operatorname{Tr}_{1}$ and $\operatorname{Tr}_{5}$ with an $\mathrm{LC}_{50}$ of $2 \times 10^{5}, 2 \times 10^{5}, 2.3 \times 10^{5}, 2.3 \times 10^{5} \mathrm{ppm}$ 
,respectively. The LC values obtained was necessary to kill $50 \%$ of $S$. littura larval population in a certain period. The virulence of strains showed that $\operatorname{Tr}_{4}$ require a lower concentration was needed to be lethal $100 \%$ of larvae population. Aranda et al. (1996) reported that Bt aizawai HD68 has two genes [ cry 1A ( a) , cry 1D] related to toxicity, while $B t$ thuringiensis 4412 has only one ( cry $1 \mathrm{~B}$ ). The same authors observed $\mathrm{LC}_{50}$ value of $77 \mathrm{mg} / \mathrm{cm}^{2}$ for cry $1 \mathrm{D}$ and above $2.000 \mathrm{mg} / \mathrm{cm}^{2}$ for cry $1 \mathrm{~A}$ (a, b, c ). On the other hand, Chak et al. ( 1994 ) described a new strain of $B t$ with cry1 ( a,b ), cry $1 \mathrm{C}$ and cry $1 \mathrm{D}$ genes, and emphasized that the high activity of Bt aizawai strains to $S$. frugiperda may be related to the interaction between cry1A and cry $1 \mathrm{D}$ genes .It must be pointed out that the mortality obtained by the efficient transconjugants may be due to the interaction between crystal genes from $B t$ and chitinase genes from
Serratia marcescens which enhanced the possibility to use moderated toxic proteins as a helpful tool to control Spodoptera littoralis population in integrated pest management systems in cotton fields. The sublethal effects of Bt on S. littoralis were pointed out by Regev et al. (1996), who determined the sublethal doses which caused reaction in consumption and delay in larvae and pupae development . Meanwhile, these effects were temporary and the intensity decreased with the growth of larvae. The mechanism by which gut bacteria mediate $B$. thuringiensis induced killing requires further elucidation, as do the different responses to gut bacteria in various insect species. From a pest management perspective, the ability of B.thuringiensis - induced mortality of other lepidopteran species may provide opportunities for increasing susceptibility or preventing resistance.

Table 4. Lethal concentrations of recombinant bioinsecticides against cotton leaf worm under laboratory conditions.

\begin{tabular}{|c|c|c|c|c|c|c|c|c|}
\hline \multirow{2}{*}{ Bioinsecticides } & \multicolumn{2}{|c|}{$\mathbf{L C}_{30}$} & \multicolumn{2}{|c|}{$\mathbf{L C}_{50}$} & \multicolumn{2}{|c|}{$\mathbf{L C}_{70}$} & \multicolumn{2}{|c|}{$\mathrm{LC}_{90}$} \\
\hline & $\mathbf{p p m}^{\dagger}$ & TI & $\mathbf{p p m}^{\dagger}$ & TI & $\mathbf{p p m}^{\dagger}$ & TI & $\mathbf{p p m}^{\dagger}$ & TI \\
\hline$\overline{\mathrm{Bt}_{3}}$ & 0.025 & 88.00 & 02.22 & 86.90 & 04.41 & 87.30 & 06.61 & 87.14 \\
\hline$S M$ & 0.028 & 78.57 & 02.45 & 78.77 & 04.87 & 79.00 & 07.30 & 78.50 \\
\hline $\mathrm{Mp}$ & 0.026 & 83.28 & 02.33 & 82.83 & 04.64 & 83.15 & 06.95 & 83.02 \\
\hline $\operatorname{Tr}_{1}$ & 0.122 & 18.00 & 02.30 & 83.90 & 04.50 & 85.50 & 06.70 & 85.97 \\
\hline $\operatorname{Tr}_{2}$ & 0.294 & 07.48 & 02.69 & 71.70 & 05.09 & 75.60 & 07.49 & 76.90 \\
\hline$B t_{2}$ & 0.250 & 08.80 & 2.75 & 70.18 & 05.25 & 73.30 & 07.75 & 74.30 \\
\hline$S M$ & 0.028 & 78.57 & 2.45 & 78.77 & 04.87 & 79.00 & 07.30 & 78.50 \\
\hline MP & 0.138 & 46.04 & 2.54 & 76.50 & 04.94 & 78.20 & 07.35 & 78.66 \\
\hline $\mathrm{Tr}_{3}$ & 0.704 & 03.13 & 2.75 & 70.18 & 04.79 & 80.40 & 06.84 & 84.20 \\
\hline $\operatorname{Tr}_{4}$ & 0.022 & 100.00 & 1.93 & 100.0 & 03.85 & 100.0 & 05.76 & 100.0 \\
\hline$B t_{4}$ & 0.074 & 29.70 & 2.29 & 84.27 & 04.51 & 85.40 & 06.74 & 85.45 \\
\hline$S M$ & 0.028 & 78.57 & 2.45 & 78.77 & 04.87 & 79.00 & 07.30 & 78.50 \\
\hline $\mathrm{Mp}$ & 0.050 & 56.49 & 2.31 & 83.55 & 04.57 & 84.27 & 06.84 & 84.23 \\
\hline $\operatorname{Tr}_{5}$ & 0.209 & 10.50 & 2.30 & 83.90 & 04.39 & 87.69 & 06.48 & 88.88 \\
\hline $\operatorname{Tr}_{6}$ & 0.062 & 35.48 & 2.00 & 96.50 & 03.96 & 97.20 & 05.90 & 97.60 \\
\hline$B t_{1}$ & 5.000 & 00.44 & 9.73 & 19.80 & 14.47 & 26.60 & 19.21 & 29.98 \\
\hline$S M$ & 0.028 & 78.57 & 2.45 & 78.77 & 04.87 & 79.00 & 07.30 & 78.50 \\
\hline $\mathrm{Mp}$ & 2.500 & 41.86 & 6.03 & 51.30 & 9.46 & 54.87 & 13.08 & 56.50 \\
\hline $\operatorname{Tr}_{7}$ & 0.023 & 95.65 & 2.00 & 96.50 & 3.97 & 96.97 & 05.95 & 96.80 \\
\hline $\operatorname{Tr}_{8}$ & 0.150 & 14.66 & 2.83 & 68.19 & 5.52 & 69.75 & 08.21 & 70.16 \\
\hline
\end{tabular}

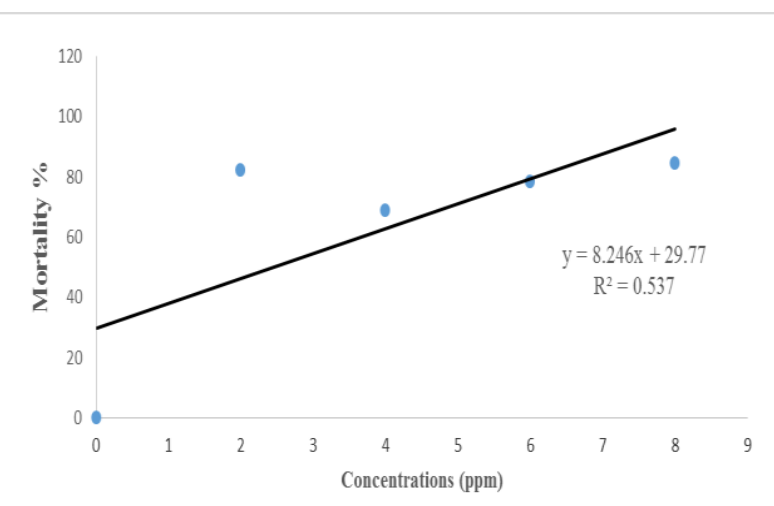

Figure 4. Toxicity regression lines of Serratia marcescens $(\mathrm{Sm})$ against $\mathrm{S}$. littoratis larvae treated with bioinsecticide for six days.

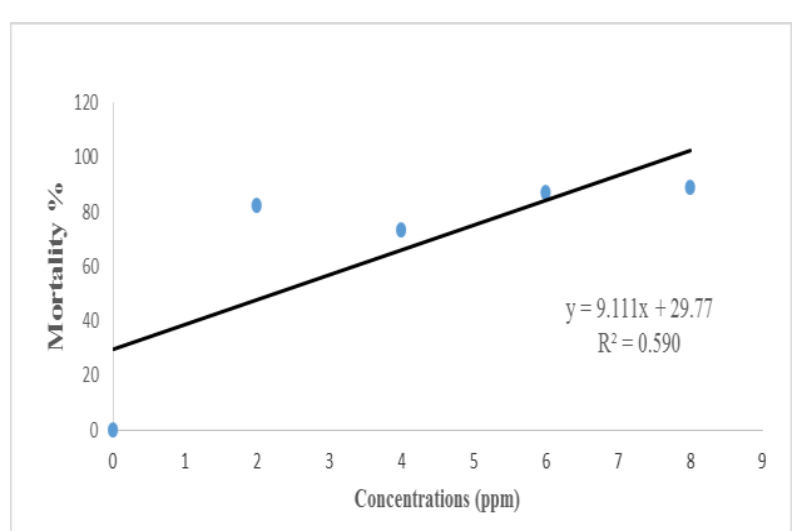

Figure 5. Toxicity regression lines of Bacillus thuringiensis $\left(B t_{1}\right)$ against $S$. littoratis larvae treated with bioinsecticide for eight days. 


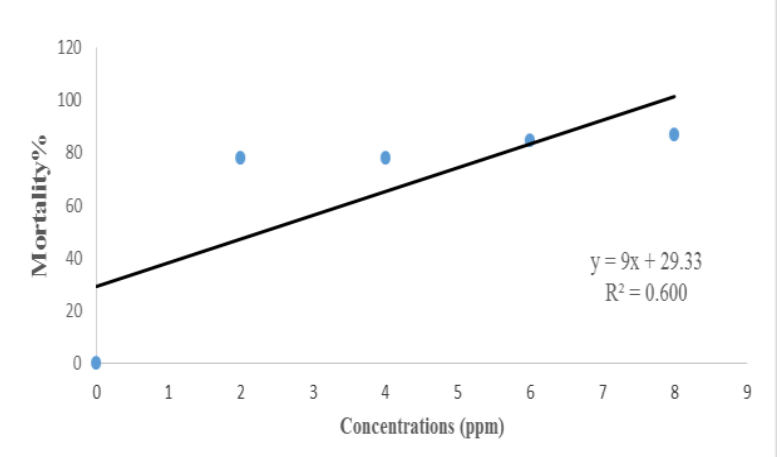

Figure 6. Toxicity regression lines of Bacillus thuringiensis $\left(\mathrm{Bt}_{2}\right)$ against $S$. littoratis larvae treated with bioinsecticide for eight days.

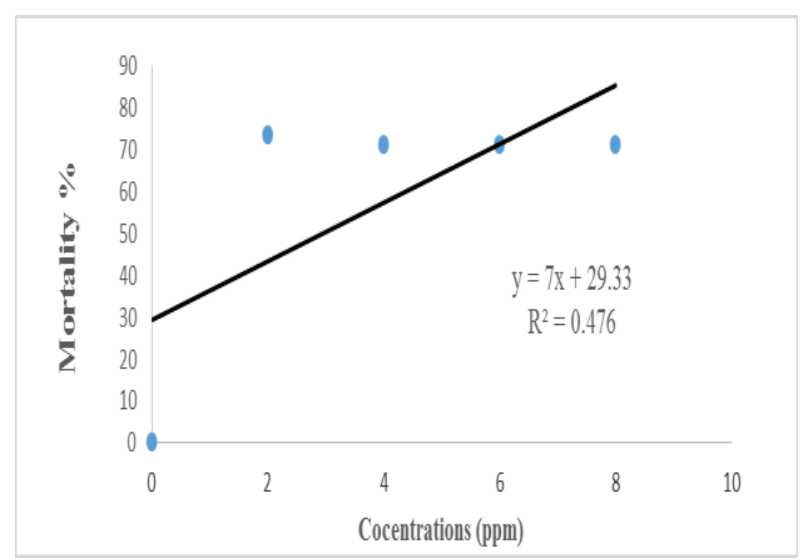

Figure 7. Toxicity regression lines of Bacillus thuringiensis $\left(\mathrm{Bt}_{3}\right)$ against $S$. littoratis larvae treated with bioinsecticide for six days.

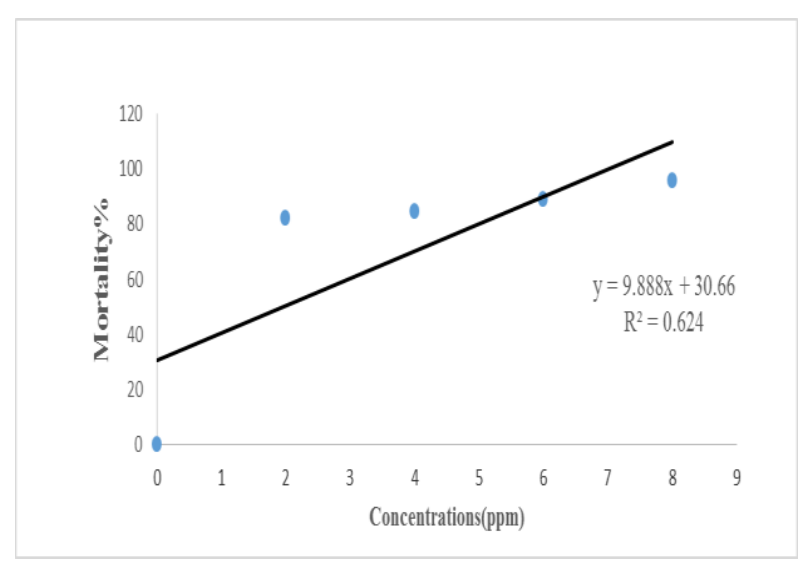

Figure 8. Toxicity regression lines of Bacillus thuringiensis $\left(\mathrm{Bt}_{4}\right)$ against $S$. littoratis larvae treated with bioinsecticide for six days.

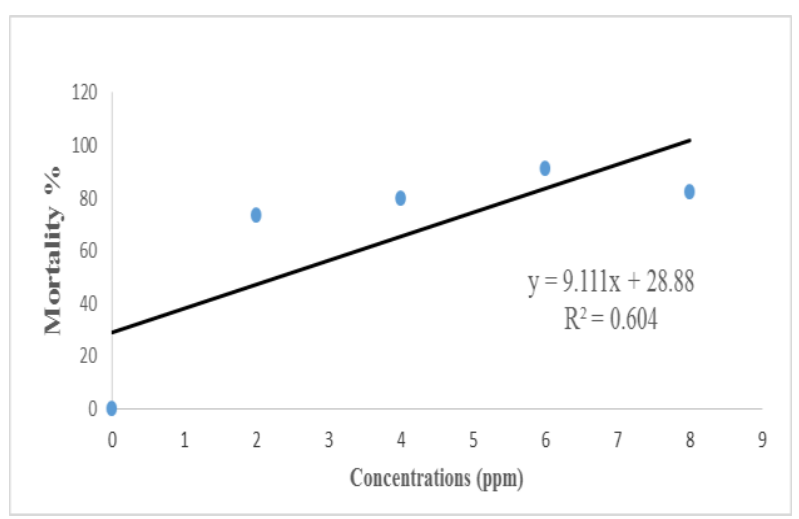

Figure 9. Toxicity regression lines of $\operatorname{Tr}_{1}$ resulted from conjugation between Bacillus thuringiensis $\left(B t_{3}\right) \mathrm{X}$ Serratia marcescens $(\mathrm{Sm})$ against $S$. littoratis larvae treated with bioinsecticide for six days.

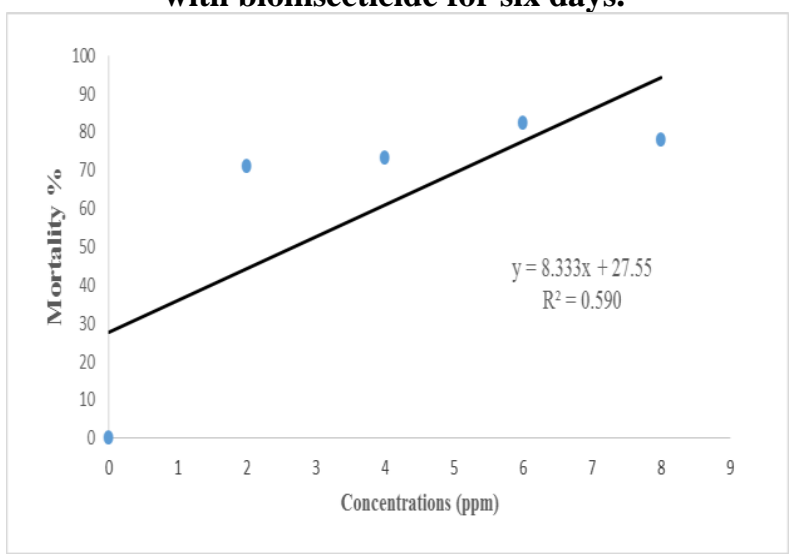

Figure 10. Toxicity regression lines of $\mathrm{Tr}_{2}$ resulted from conjugation between Bacillus thuringiensis $\left(\mathrm{Bt}_{3}\right) \mathrm{X}$ Serratia marcescens $(\mathrm{Sm})$ against $S$. littoratis larvae treated with bioinsecticide for five days.

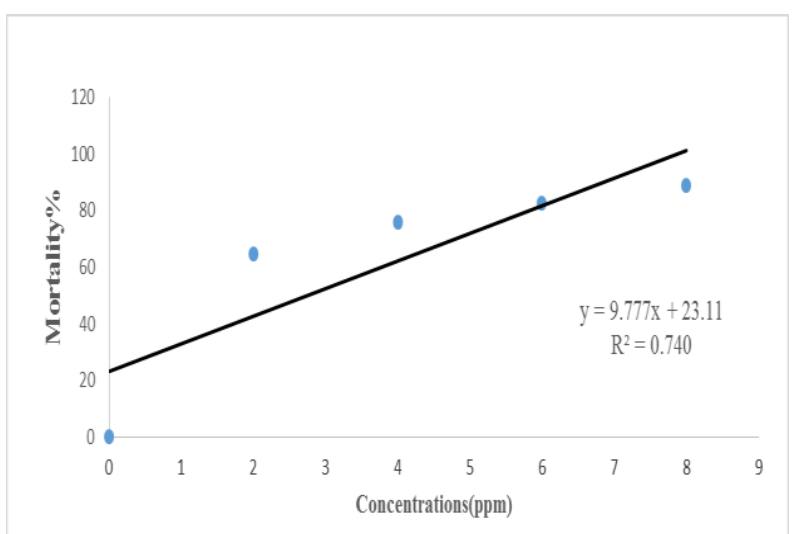

Figure 11. Toxicity regression lines of $\operatorname{Tr}_{3}$ resulted from conjugation between Bacillus thuringiensis $\left(\mathrm{Bt}_{2}\right) \mathrm{X}$ Serratia marcescens $(\mathrm{Sm})$ against $S$. littoratis larvae treated with bioinsecticide for six days. 


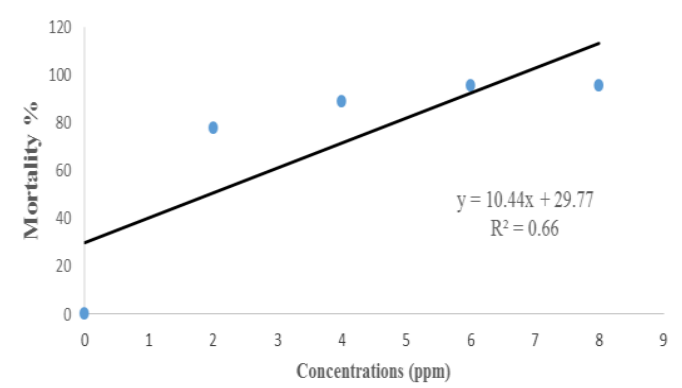

Figure 12 . Toxicity regression lines of $\mathbf{T r}_{4}$ resulted from conjugation between Bacillus thuringiensis $\left(\mathrm{Bt}_{2}\right) \mathbf{X}$ Serratia marcescens $(\mathrm{Sm})$ against $S$. littoratis larvae treated with bioinsecticide for eight days.

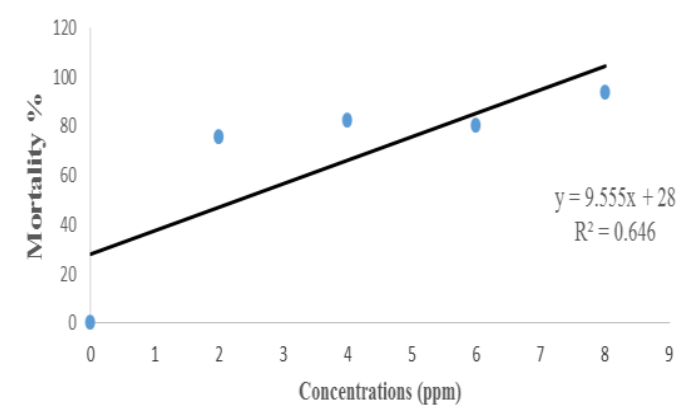

Figure 13. Toxicity regression lines of $\operatorname{Tr}_{5}$ resulted from conjugation between Bacillus thuringiensis $\left(\mathrm{Bt}_{4}\right) \mathrm{X}$ Serratia marcescens $(\mathrm{Sm})$ against $S$. littoratis larvae treated with bioinsecticide for six days.

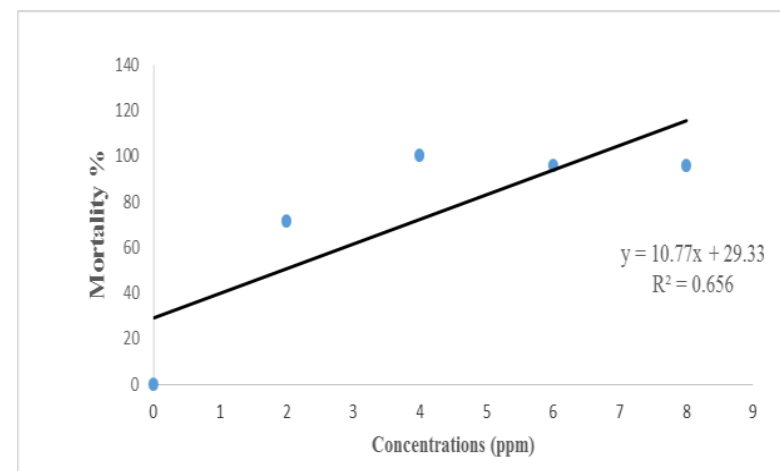

Figure 14. Toxicity regression lines of $\operatorname{Tr}_{6}$ resulted from conjugation between Bacillus thuringiensis $\left(\mathrm{Bt}_{4}\right) \mathrm{X}$ Serratia marcescens $(\mathrm{Sm})$ against $S$. littoratis larvae treated with bioinsecticide for eight days.

This contribution of $B t$ caused host mortality suggested that toxin feeding caused a transition of therwise bening bacteria into opportunistic pathogenes in some, but not all hosts ( Broderick et al. 2009 ). In this study bacterial transconjugants were constructed between $B t$ and Serratia to obtain recombinant isolates expressed crystal and chitinase genes for increasing susceptibility of cotton leafworm populations to recombinant bioinsecticide, as well as, preventing resistance to bioinsecticides.

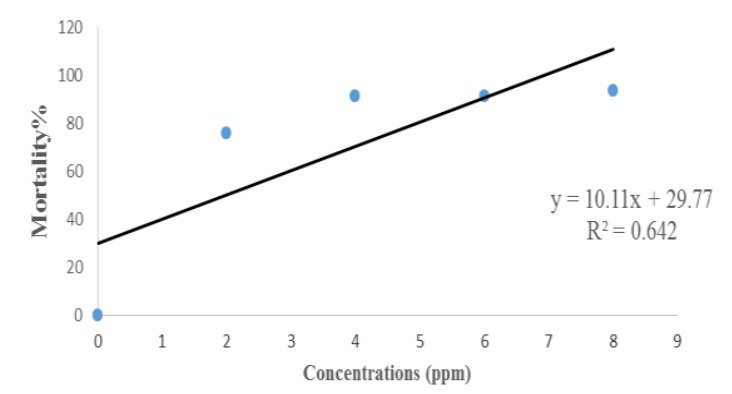

Figure 15. Toxicity regression lines of $\mathrm{Tr}_{7}$ resulted from conjugation between Bacillus thuringiensis $\left(\mathrm{Bt}_{1}\right) \mathrm{X}$ Serratia marcescens (Sm) against larvae $S$. littoratis larvae treated with bioinsecticide for ten days.

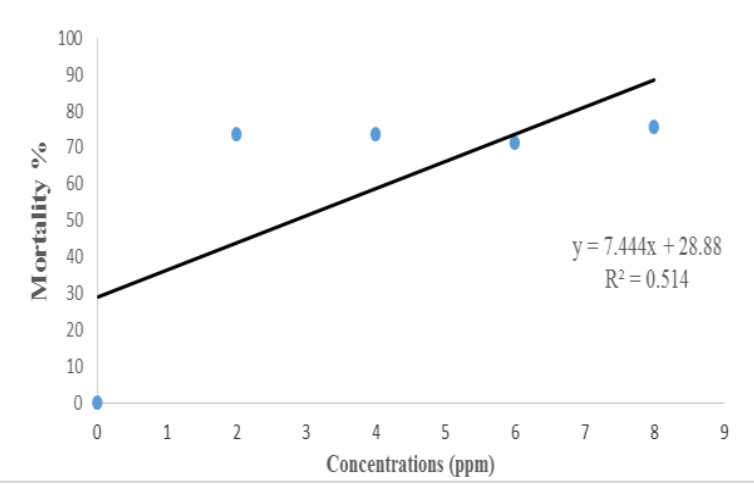

Figure 16. Toxicity regression lines of $\operatorname{Tr}_{8}$ resulted from conjugation between Bacillus thuringiensis $\left(\mathrm{Bt}_{1}\right)$ X Serratia marcescens $(\mathrm{Sm})$ against $S$. littoratis larvae treated with bioinsecticide for three days.

In conclusion, increasing toxicity of $B t$ strains via genetic techniques as seen in this study reduce the dosage of microbial product needing in pest control and saving plant protection expenses. Some of bioinsecticides induced in this study caused 100\% mortality within eight days such as transconjugants $\operatorname{Tr}_{2}$, which appeared significant mortality in relation to the mid parents.Thus,recombinants isolates provides interesting aspect in integrated pest management .

\section{REFERENCES}

Abbott, W.S.1925. A method for comparing the effectiveness of an insecticide. J. Econ. Entomol. 18: 265-267.

Aggrawal,C.S, Paul, V. Tripathi, B. Paul, and M.d.A., Khan.2015.Chitinolytic activity in Seratia marcescens (strain SEN) and potency against different larval instars of Spodoptera litura with effect of sublethal doses on insect development .Biocontrol 60:631-640.

Arakane, Y and S. Muthukrishnan. 2010. Insect chitinase and chitinase-like proteins. Cell Mol Life Sci 67:201-216. 
Aranda, E.; J. Sanchez, M. Peferoen, L. Guereca and A. Bravo.1996. Interaction of Bacillus thuringensis crystal proteins with the midgut epithelial cells of Spodoptera frugiperda (Lepidoptera : Noctuidae ). J. Invert . Pathol., 68:203-212.

Aronson, A.I.; E. S. Han; M.c. Gaughey; W. D. Johnson 1991.Thesolubility of inclusion proteins from Bacillus thuringiensis independent upon protoxin composition and is a factor in toxicity to insects. Appl Environ Microbiol. 57:981-986.

Ausubel, F. M., R. Brent, R. E. Kingston, D. O. Moore , J S. Seidman, J. A. Smith, and K. Struhl.1987. Current Protocols in Molecular Biology. New York: Wiley.

Bautista, J. R. and F.G. Teves. 2013. Antibiotic susceptibility testing of isolated Bacillus thuringiensis from three soil types around lligan City, Philippines. African journal of microbiology research 7(8):678-682.

Bernhard, K., H. Schempf and W. Goebel. 1978. Bacteriocin and antibiotic resistance plasmids in Bacillus cereus and Bacillus subtilis. Journal of Bacteriology 133: 897-903.

Biedendieck, R., Y. Yang, W. D. Deckwer and D. Jahn.2007. Plasmid system for the intracellular production and purification of affinity tagged proteins in Bacillus megaterium .Biotechnol bioeng 96:525-538.

Broderick, A. M., C.J., Robinson; M.D., Mc Mahon, J. Holt and k. f. Raffa.2009. Contributions of gut bacteria to Bacillus thuringiensis-induced mortality vary across a range of Lepidoptera. BMC Biology. $7: 11$

Carlson, C. R., D.A., Caugant and A.B., Kolst.1994 .Genotypic diversity among Bacillus cereus and Bacillus thuringensis strains. Appl. Microbial., 60:1719-1725.

Chak, K. F.; M.Y., Tseng and T., Yamamoto. 1994.Expression of the crystal protein gene under the control of the -amalas promoter in Bacillus thuringensis strains. Appl Environ Microbial. 60: 2304-2310

Chandrasekaran,R., K. Revathi, S. Nisha, S. A. Kirubkaran and S. S. Nathan.2012. Physiological effect of chitinase from Bacillus subtilis againstthe tobacco cutworm Spodoptera litura Fab, Pestic. Biochem. Physiol. 104 : 65-71.

Chari, M. S., G. Ramprasad, S. Sitaraman and P. S. N. Murthy.1990. Bioefficacy of neem formulation against Spodoptera littura F. in Tobacco nurseries .Proceedings of the Symposium on Botanical pesticides in integrated pest Management, pp:145153

Chilcutt, C. F., and B. E. Tabashnik. 1997a.Host -mediated competition between the pathogen Bacillus thuringensis production of chitosan oligosaccharides. Appl. Environ. Microbiol. 45224531 .

Chuan, D. L.2006. Review of fungal chitinases, Mycopathologia. 161: 345-360.
Collins, C.H. and P.M. Lyne. 1985. Microbiological Methods. $5^{\text {th }}$ Edition. Butterworth and Co (Publishers) Ltd. Environmental Engineering. 116(5):805-828.

Crickmore, N.2006.Beyond the spore-pest and future developments of Bacillus thuringensis as a biopesticide .J Appl Microbial. 101:616-619.

Dominguez, W., D. J. O'Sullivan.2013. Developing an efficient and reproducible conjugation-based gene transfer system for Bifidobacteria ; Microbiology (United Kingdom). ; 159 (2):328-338.

Ebrahimi, M., A. sahragard and R. T. Hossanloui. 2012. Effect of Bacillus thuringensis var .Kurstaki on survival and mortality of mature stages of Diadegma insulare parasitizing Plutella xylostella Phytoparasitica40:393-401.

Ellar,D. J. and J. A. Posgate.1974. In Spore Research 1973 (Barker, A. N., Gould,G. W. \& Wolf, J., eds.), pp. 21-40, Academic Press, London.

Fan, Y.H., W.G. Fang, S.J. Guo, X. Q. Pei, Y. G. Zhang, Y. H. Xiao, D. Li., K. Jin, M.J. Bidochka and Y. Pei. 2007. Increased insect virulence in Beauveria bassiana strains over expressing an engineered chitinase, Appl. Environ. Microbiol. 73 : 295-302.

Fang, S.L., L. Wang, W. Guo, X. Zhang, D. H. Peng, C. P. Luo, Z. I. Yu and M. Sun. 2009. Bacillus thuringiensis Bel protein enhances the toxicity of Cry1Ac protein to Helicoverpa armigera larvae by degrading insect intestinal mucin. Appl. Environ. Microbiol., 75, 5237-5243.

Finney, D. J .1971. Probit analysis, 3rd ed. London: Cambridge University.

Fitches, E., H. Wilkerson, H. Bell, D. P. Bown, J. A. Gatehouse and J. P. Edwards. 2004. Cloning, expression and functional characterization of chitinase from larvae of tomato moth (Lacanobia oleracea): a demonstration of the insecticidal activity of insect chitinase, Insect Biochem. Mol. Biol. 34: 1037-1050.

Gogerten, J. P., A. G. Senejani, O. Zhaxybayevan, L. Olendezenski and E. Hilario. 2002. Structure, function, and evolution. Annu. Rev. Microbiol. 56: 263-287.

Gordon, S. A. B., K. Stewart., E.Johnstone., Hagelberg and D. J.Ellar.1981. Commitment of bacterial spores to germinate A measure of the trigger reaction. iochem. J. 198, 101-106.

Grinsted, J., P. M. Bennett.1990. Methods in Microbiology: Plasmid Technology (second edition) Published by Academic Press ISBN 10: 0123039703 ISBN 13: 9780123039705.

Harris, E. D.1992. Regulation of antioxidant enzymes. FASEB J 6:2675-2683.

Harris, ZL.;SR .Davis-Kaplan .; JD .Gitlin and J .Kaplan. 2004. A fungal multicopper oxidase restores iron homeostasis in aceruloplasminemia. Blood 103 (12):4672-3. 
Hentges P., B. V. Driessche, T. L. Vandenhaute and A.M. Carr .2005. Three novel antibiotic marker cassettes for gene disruption and marker switching in Schizosaccharomyces pombe. Yeast. 15; 22(13):1013-9.

Hernadez , J .L. L.1988.Evaluation de la toxicite de Bacillus thuringensis sur Spodoptera frugiperda .Entomoph .,32:163-171.

Hu, G., J. L. Jurat-Fuentes and M. J. Adang. 2004. Fluorescent-based assays establish Manduca sexta Bt-R1a cadherin as a receptor for multiple Bacillus thuringiensis Cry1A toxins in Drosophila S2 cells. Insect Biochem. Mol. Biol. 34: 193-202.

Isman, M. B., C. M. Miresmailli and L. D. Bainard 2007.Essential oil based pesticides : new insights from old chemistry .In :Pesticide chemistry, $\mathrm{H}$. Ohkawa and H Miyagawa ,(Eds): wiley, Weinheim, pp:113.

Jain, P. K., S. Ramachandran, V. Shukla, D. Bhakuni and S. Verma. 2009. Characterization of metal and antibiotic resistance in bacterial population from copper mining industry. J. Integr. Biol: 6, 57-61.

Karamanlidou G., A. F. Lambropoulos, S. I. Koliais, T. Manousis and D. Ellar. 1991. Toxicity of Bacillus thuringiensis to laboratory populations of the olive fruit fly (Dacus oleae). Appl Environ Microbiol . 57,2277-82.

Korrat, E. E., A. E. Abdelmonem, A. A. R. Helalia, H. M. S. Khalifa.2012 . Toxicological study of some conventional and nonconventional insecticides and their mixtures against cotton leaf worm, Spodoptera littoralis (Boisd.) (Lepidoptera: Noectudae). Annals of Agricultural Science 57(2), 145-152.

Kramer, K. J., J. Muthukrishnan and F. W. Lowell. 1997. Chitinases for insect control , jn: N.Carozzi ,M.Koziel(Eds ) ,Advances in insect control : The Role of Transgenic plants ,Taylor and Francis ,Bristol ,pp.185-193.

Luna, V. A., D. S. KING, J. Gulledge, J. Gulledge and J. Cattani. 2007. Susceptibility of Bacillus anthracis, Bacillus cereus, Bacillus mycoides, Bacillus pseudo mycoides and Bacillus thuringiensis to 24 antimicrobials using Sensititrew automated microbroth dilution and Etest agar gradient diffusion methods. Journal of Antimicrobial Chemotherapy, v. 60, n. 3, p. 555-567.

Mahadevan, B. and D. L. Crawford.1997.Enzme Microb.Technol.20:489-493.

Merzen dorfer, H. and L. Zimoch.2003. Chitin metabolism in insects structure, function and regulation of chitin synthases and chitinases. J Exp Biol 206:43934412.

Mohan, M. and G. T. Gujar .2000 .Susceptibility pattern and development of resistance in the diamondback moth ,Plutella xylostella L., to Bacillus thuringensis Berl .var. kurstaki in india Management Science 56:189-194.

Moore, I. and A. Navon. 1973. Studies of the susceptibility of the cotton leafworm , Spodoptera littoralis (Boisduval ), to various strains of Bacillus thuringensis .Phyto parasitica 1: 23-32.
Nation, J. L. 2001. Insect physiology and biochemistry. CRC, Boca Raton, pp 40-41.

Nguyen, D.H., M. Nakai., J. Takatsuka., S. Okuno and Y. Kunimi .2005. Interaction between a nucleopolyhedro -virus and the braconid parasitoid Meteorus plucharicornis (Lepidoptera :Braconidae ) in the larvae of Spodoptera litura (Lepidoptera: Noctuidae). Applied Entomology and zoology. 40,325-334.

Regev, A., M. Keller, N. Strizhov, B. sheh and Z. KonczKalman.1996.Synergistic activity of a Bacillus thuringensis $\sigma-$ endotoxin and a bacterial endochitinase against Spodoptera littoralis larvae. Appl Environ Microbiol. 62:3581-3586.

Ren, G., H. Liy-X xioung, J. Wang and G. Zhao.1995. Characters and insecticidal polypeptide of a new strain of Bacillus thuringiensis subspecies. Kenyae in China. Wei-Sheng-Wu-Hsueh-Pao., 35:101-107.

Schroder, G. and E. Lanka. 2005. The mating pair formation system of conjugative plasmids, a versatile secretion machinery for transfer of proteins and DNA. plasmid 54,1-25.

Snedecor G. W., and W. G Cochran.1955. Statistical methods applied to experiments in agriculture and biology. 5th ed. Ames, Iowa: Iowa State University.

Someya, N., S. Ikeda, T. Morohoshi et al.2011. "Diversityofculturable chitinolytic bacteria from rhizospheres of agronomic plants in Japan," Microbes and Environments, vol. 26, no. 1, pp. 714.

Somkiat, P., A. Thamchaipenet and B. Panijpan.2007. Conjugation in Escherichia coli. Biochemistry and Molecular Biology 35 (6): 440-445. DOI: $10.1002 / b m b .113$

Tabashnik, B. E., N. L. Cushing, N. Finson and M. W. Johnson. 199. Field development of resistance to Bacillus thuringensis in diamondback moth (Lepidoptera: Plutellidae). Journal of Economic Entomology ,83,1671-1676.

Tan, F.R.; J .Zhu.; J .Tang.; X.M Tang.; S.Q .Wang.; , A.P. Zheng and P. Li. 2006. Cloning and characterization of two novel crystal protein genes, cry54Aal and cry30Fal, from Bacillus thuringiensis strain BtMC28. Curr. Microbiol. 58: 654-659.

Toda M.; S .Okubo.; R .Hiyoshi and T .Shimamura (1989). Antibacterial and bactericidal activities of Japanese green tea. Jpn. J. Bacteriol. 44(4): 669-672.

Wang, A., Pattemore, J., Ash, G. Williams, A.; Hane and J. Draft .2013.Genome sequence of Bacillus thuringiensis strain DAR 81934, which exhibits molluscicidal activity. J. Bacteriol., 1, e00175-12.

Wang, H. H., M. Manuzon, M. Lehman, K. Wan, H. Luo, T. E. Wittum, A. Yousef, and L. O. Bakaletz. 2006. Food commensal microbes as a potentially important avenue in transmitting antibiotic resistance genes. FEMS Microbiol.

Wu, N., M. Qiao, B. Zhang, W.D. Cheng and Y. G. Zhu. 2010. Abundance and diversity of tetracycline resistance genes in soils adjacent to representative swine feedlots in China. Environ Sci Technol 44:6933-6939. 


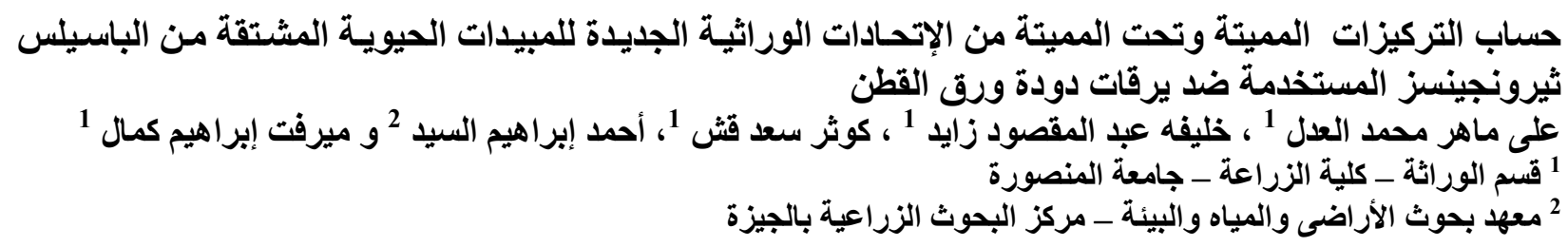

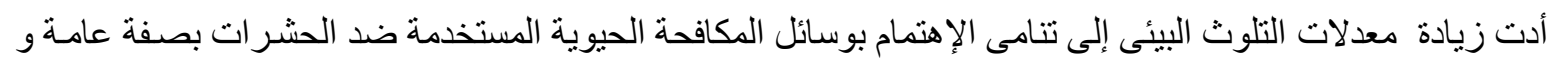

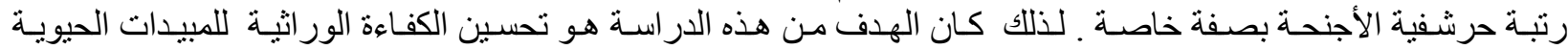

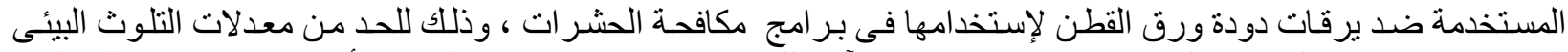

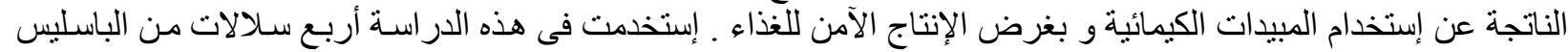

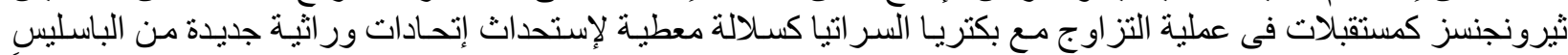

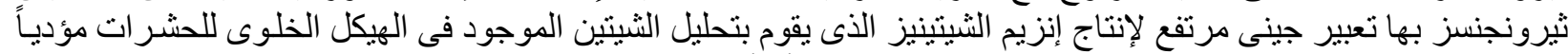

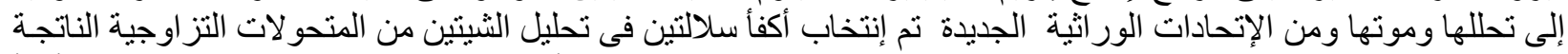

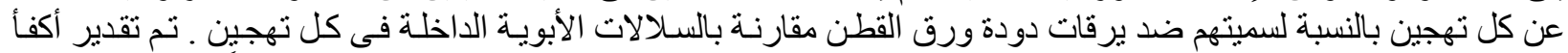

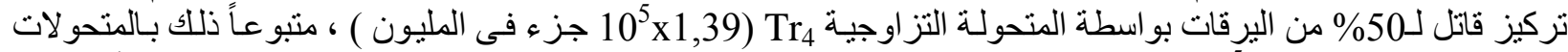
التز اوجية أريز

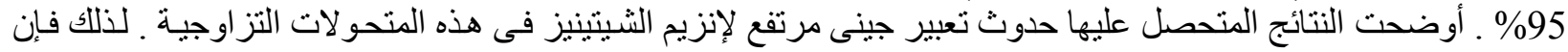

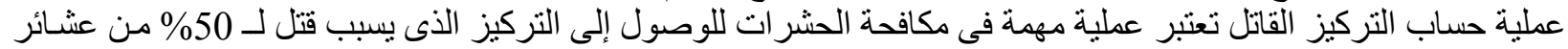

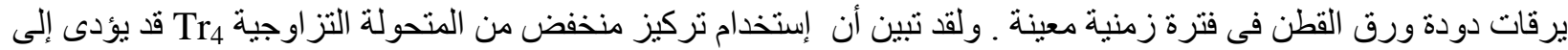

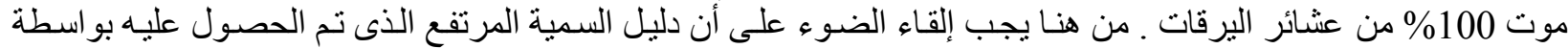

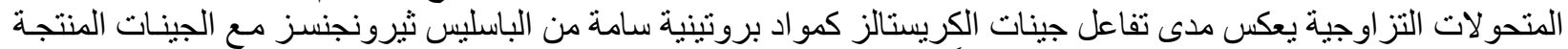

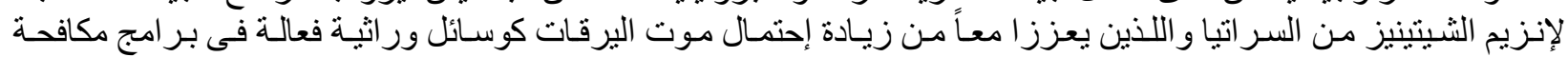

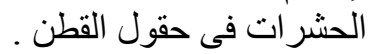

